\title{
Modern Muslims' Online Struggle: Countering Islamophobia One Tweet at a Time
}

\section{SAHAR KHAMIS}

University of Maryland, College Park

ORCID No: 0000-0001-9073-4937

\begin{abstract}
This commentary sheds light on some of the most creative online campaigns which have been launched to counter Islamophobia and overcome the negative stereotypes and skewed (mis)representations of Islam and Muslims, especially in the West. It provides a number of scholarly definitions of Islamophobia and explains why, and how, social media could act as a double-edged sword, which may fuel Islamophobia, on the one hand, while providing effective tools to counter it, on the other hand. It highlights several examples illustrating both effects of the social media, while focusing on the factors behind the success of some online countering Islamophobia campaigns, such as the amplification of Muslims' voices, including gendered voices; the deployment of humor; and the selection of suitable strategies, tactics, and tools. It concludes with a few thoughts on what needs to be done to ensure the success and continuation of countering Islamophobia efforts, moving forward.
\end{abstract}

Keywords: Islamophobia, Cyberspace, Social Media, Muslims, Online Campaigns 


\section{Introduction}

M uslims globally are using the internet, not just as a window to see and be seen by the rest of the world, but also as a tool with which to push back against the many attempts to sideline them, profile them, stigmatize them and silence them. ${ }^{1}$ Their efforts to deploy digital media as a platform that gives voice to the voiceless, thus helping them to amplify and spread their messages, became particularly important in the midst of the rising wave of Islamophobia after 9/11, especially in the West. With the alarming increase in incidents of hatred against Muslims worldwide and the dangerous new wave of Islamophobia that has been witnessed more recently, many Muslims have resorted to online campaigns to fight against negative misrepresentations, rectify their images, and spread correct awareness about their faith and traditions, their multifaceted identities and lived realities. This commentary provides various examples illustrating how different groups of Muslims are engaging in tireless online efforts to achieve all of these goals.

\section{Definitions of Islamophobia}

The idea of fearing a certain group of people because of their culture, race, traditions, religious beliefs, or simply because they are different is not new. It has been around for centuries. This process of ethnic, racial, and religious profiling has been commonly referred to as stereotyping. One example of the process of profiling and stereotyping the 'Other' is Islamophobia.

Islamophobia could be defined as "an exaggerated fear, hatred, and hostility toward Islam and Muslims that is perpetuated by negative stereotypes resulting in bias, discrimination, and the marginalization and exclusion of Muslims from social, political, and civic life." ${ }^{2}$ Its spread has prompted "an increasingly visible 'backlash' against Muslims across Europe and the United States." 3 The term "backlash' encompasses all of the negative messages received by Muslims and all harmful acts against them, whether physical, psychological, or both. This includes the controversial cartoon drawings of Prophet Muhammad by Danish artists in $2006^{4}$ that triggered negative reactions among many Muslims and some non-Muslims.

Some authors define Islamophobia as "an unfounded hostility towards Muslims, and, therefore, fear or dislike of all or most Muslims," ${ }^{5}$ while others define it as "an allegedly irrational fear of losing life or liberty to Islamic rule merely because the laws, sacred texts, and traditional practices of Islam demand the submission of culture, politics, religion, and all social expression." ${ }^{6}$ This last definition, unlike previous ones, mentions 'losing life' as a direct result of Islam. This fear could be attributed to the fact that many terrorist attacks are covered extensively and disproportionately, on national media in the West, especially if the attacker happens to have an Arab or a Muslim name, creating an association in the minds of 
Western audiences between Muslims and acts of terrorism. However, only a very tiny fringe of the world's 1.8 billion Muslims support terrorism, let alone engage in it.

There is no doubt that the rise of recent international trends, such as right-wing politics, populism, and White Supremacy, and the rhetoric associated with them, especially from some of the political leaders in Europe and the United States in recent years, have fueled Islamophobic sentiments, resulting in attacks on mosques, Islamic centers, and Muslim individuals on an unprecedented scale. These Islamophobic acts have a greater impact on those with visible Muslim identifies, such as women who wear the hijab (Islamic headscarf), for example.

Muslims in Europe suffer from different forms of discrimination, including racial and religious profiling, and sometimes even restrictions on their rights to adhere to various aspects of their Muslim faith. One glaring example is France's repeated efforts to impose restrictions on Muslim women's religious attire. The most recent of such efforts is France's 2021 decision to ban girls under eighteen years of age from wearing the hijab in public, and prohibiting mothers wearing the hijab from accompanying their children on school field trips. ${ }^{7}$ These decisions are just the latest among a series of actions by the French government aimed at restricting the hijab in France. ${ }^{8}$ These include banning the wearing of the hijab in public schools in France, banning the burkini (the

\section{Muslims in Europe suffer}

from different forms of

discrimination, including

racial and religious profiling,

and sometimes even

restrictions on their rights to

adhere to various aspects of their Muslim faith

modest, religiously compliant swimwear worn by some Muslim women), and banning the niqab (full-face covering) by law in 2010 -an action that was subsequently critiqued by the UN Human Rights Commission as an unjustified decision that disproportionately targets the minority of Muslim women who wear it, thereby violating their rights of religious freedom. ${ }^{9}$

Islamophobia has been steadily on the rise in the United States since the terrorist attacks of 9/11, which marked a seismic geopolitical shift in the portrayal of Muslims across the media. It changed people's perceptions of Islam and made them anxious and fearful of an entire group of people. The attacks made people wonder if all Muslims were extremists and, if they were, when would they attack again? Given that thousands of people died that day, they were right to fear terrorists, who belong to extremist groups like al-Qaeda. However, the problem was the proliferation of overgeneralized stereotypes that are still widespread, even though terrorist groups repre- 


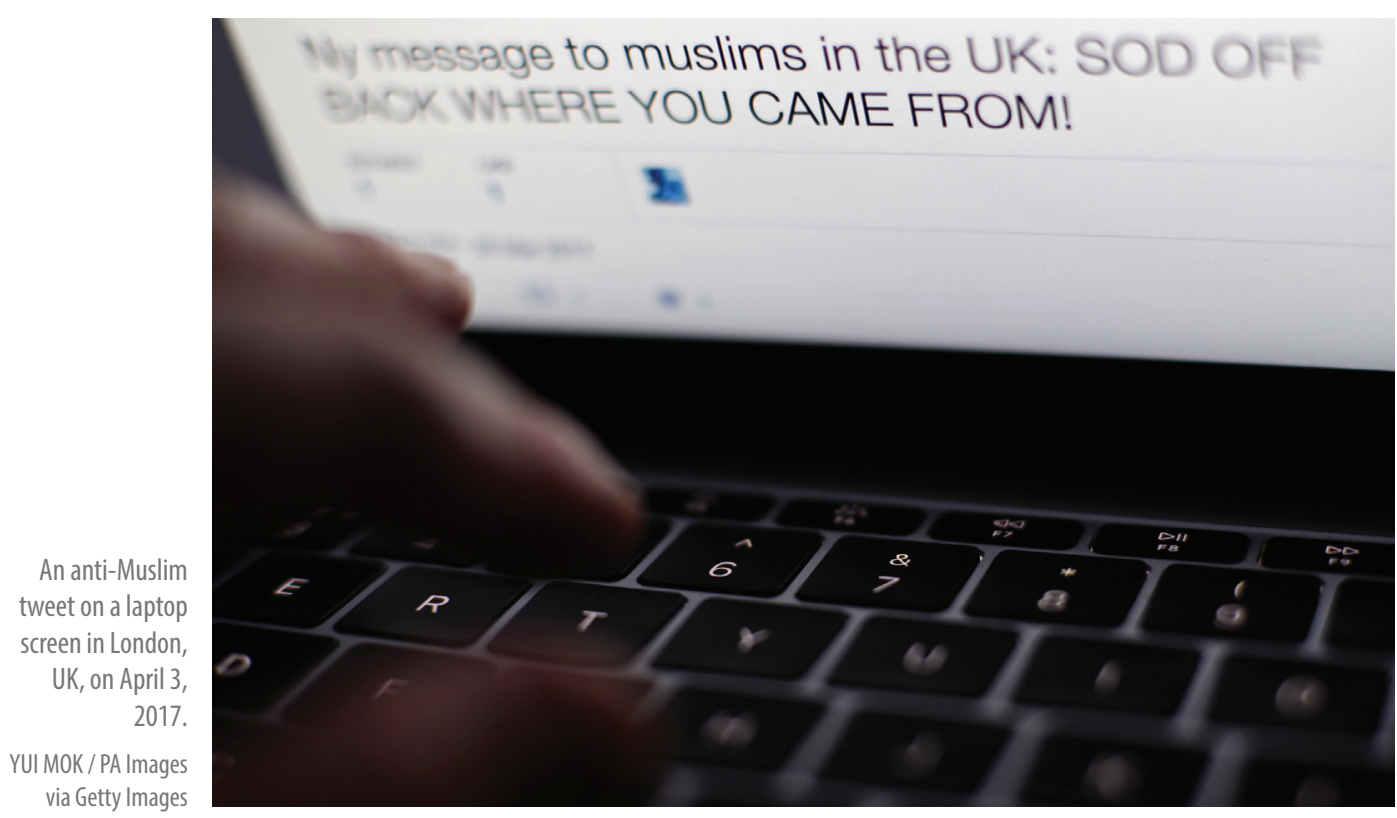

sent only a tiny fraction of the world's 1.8 billion Muslims.

Already a problem, Islamophobia became exponentially much worse after President Trump came to office in 2016. During his presidency, some of the most prominent Islamophobes launched campaigns online, using the internet to spout hatred and fuel anger and discrimination against immigrants and minorities in general, and Muslims in particular. ${ }^{10}$ This new wave of Islamophobia during Trump's presidency extended beyond mere rhetoric to include serious discriminatory policies targeting Muslims, such as the infamous Muslim Travel Ban, ${ }^{11}$ which was revoked by President Biden on the first day of his presidency.

As the above discussion clearly illustrates, we must acknowledge the com- plexities and nuances of the concept of Islamophobia by situating it within the appropriate historical, social, political, and cultural settings, as well as the appropriate temporal and spatial contextualization. Like all forms of discrimination and xenophobia, Islamophobia is part of an ever-evolving, multifaceted and elusive process that takes different forms; and is expressed through various manifestations, based on a multitude of underlying factors and shifting influences.

\section{Islamophobia Online: The Double- Edged Sword of Cyberspace}

Many of the ongoing dynamics and interactions around Islam and Muslims in cyberspace nowadays illustrate the double-edged sword effect of the internet when it comes to the complex phenomenon of Islamopho- 
bia, as the internet, with its many applications, instant and unfiltered nature, wide outreach and multiple usages provides, both the best platforms from which to spread Islamophobia, as well as the ideal tools to counter it, simultaneously. ${ }^{12}$

In regard to its negative side, some of the unmonitored and unchecked internet platforms and interactions could be considered one of the main factors behind the proliferation of Islamophobia internationally, as they provide an ideal environment for the spread of rumors, un-vetted messages, misinformation, and disinformation.

One such dangerous phenomenon is the rise of 'cloaked Facebook pages', which are "created to spread political propaganda by cloaking a user profile and imitating the identity of a political opponent in order to spark hateful and aggressive reactions." ${ }^{13}$ One example of this harmful and dangerous phenomenon is the creation of fake Islamist pages under false Muslim names to spout hatred against non-Muslims; and to spread radical, extremist ideologies, thus triggering negative and aggressive reactions from non-Muslims online and perpetuating hate speech. ${ }^{14}$

The internet also offers unfiltered platforms for the spread of content that can sometimes harm Muslims and negatively affect their image and reputation. This includes Islamophobic Twitter campaigns, such as \#BanIslam, to give just one example, which fuels anti-Muslim sentiments

\section{One such dangerous phenomenon is the rise of 'cloaked Facebook pages,' which are created to spread political propaganda}

by warning against the dangers of so-called 'Islamic extremism,' thus instilling fear and hatred in people's hearts against Islam and Muslims. Some of the recent comments that have circulated under the hashtag \#BanIslam include tweets such as, "A 24-year-old resident of an asylum-seeker center in Holland has been arrested after going on a stabbing rampage injuring seven people inside the center. The motive for the stabbing was not immediately clear. Poor WiFi signal maybe. \#BanIslam \#ReligionofPeaceLOL;" and "Continuing the policy of appeasement with the Iranian regime is a very dangerous thing; and they should know that if they do, Iranian terrorists will open the doors of their homes in the United States, and that is why the world must stand up to them \#BanIslam.." ${ }^{15}$ In a similar vein, a woman using an account called "IAmNotABotIAmAmericanPatriot" tweeted, "The Mullahs' blood lusts are insatiable. We're already witnessing the results of embracing their ideology here in our great country and the exposure to it is taking a dreadful toll. \#BanIslam \#NoSharia." 16

In a new digital world, where information exchange occurs instantly 


\section{The strategic use of humor}

in both of these campaigns

served the purpose and

helped to create a strong,

powerful, and far-reaching

impact pels some of the myths, stereotypes, and misconceptions commonly held about Muslims in general, and American Muslims in particular, such as perceiving them as new immigrants to the West, associating them collectively with extremism, radicalization, and terrorism, or thinking of them as Arabs only. ${ }^{17}$

Another good effort was the 2016 launch of an online campaign, titled \#MuslimsAreSpeakingOut, under the umbrella of the Foundation for Ethnic Understanding (FFEU) with the support of major American Muslim organizations, as part of a three-year campaign combating extremism and Islamophobia. The campaign was directed against the canard that Muslims do not speak out against terrorist attacks, citing the overwhelming condemnation of terrorist violence by virtually all Muslim leaders and organizations in the United States, and around the world. The campaign showcased their leading role in the fight against the extremists who have hijacked the narrative of Islam. It also highlights the positive contributions Muslims bring to their societies and their sustained efforts to nurture ties with other faith communities. The campaign deployed a mixture of online tools, including YouTube videos, tweets, and a Facebook page, to achieve its goals. ${ }^{18}$

Alongside these campaigns, which have focused on raising Muslim voices and highlighting Muslim identities online, other campaigns have deployed an equally effective tool, namely humor, which has proven to 
be a very effective technique in countering Islamophobia.

One good example is the \#Islamophobin pill campaign launched by the Council on American-Islamic Relations (CAIR), which was a hilarious, sarcastic, witty, and tactful campaign, suggesting that those who exhibit signs of Islamophobia, or excessive, irrational fear of Muslims, should seek healing from this disease by taking the make-believe \#Islamophobin pill until all their Islamophobic symptoms are cured. Featuring the mock pill in an online video and on various social media platforms, the campaign states, "\#Islamophobin provides multi-symptom relief for chronic Islamophobia. The maximum strength formula treats blind intolerance, unthinking bigotry, irrational fear of Muslims, and U.S. presidential election year scapegoating." ${ }^{19}$

Another online campaign that effectively deployed humor was \#MuslimsReportStuff. When presidential candidate Donald Trump answered a question by a Muslim woman during the second presidential debate about the potential danger of Islamophobia and what he is planning to do about it, he responded with an Islamophobic answer, suggesting that American Muslims should always report anything they witness that may seem remotely suspicious. This triggered the Twitter campaign by Muslims, \#MuslimsReportStuff, which was hilarious, witty, sarcastic, and bitterly funny. It included tweets like, "Attn: FBI and CIA: my 4-year-old cousin called Aryana Grande 'Ariana GRE-
NADE.' I'll keep monitoring his behavior. \#MuslimsReportStuff;" "I am Muslim. Want 2 report six Americans won the Nobel Prize this year in various sciences. ALL of them immigrants. \#MuslimsReportStuff;" "I took an extra pack of free peanuts at the car wash this afternoon. \#MuslimsReportStuff;" and "My husband did the dishes today... suspicious activity? I'll keep an eye out. \#MuslimsReportStuff." ${ }^{20}$

The strategic use of humor in both of these campaigns served the purpose and helped to create a strong, powerful, and far-reaching impact. These excellent examples illustrate the power of the internet, social media, and citizen journalism when properly used and effectively deployed. They also exemplify some of the effective strategies and tactics needed to counter Islamophobia, including combining technological savviness with cultural competency, wit, humor, intelligence, and swift reply, in addition to using the right message, through the right medium to reach the right audience at the right time.

\section{Gendered Anti-Islamophobia Campaigns: Muslim Women's Online Resistance}

A quick Google search for the term 'Muslim women' generates hundreds of photos of women totally cloaked in black garments from head to toe, and even artistic images of women confined to the harem, in a Shahrazad-like, fairytale fashion. These images never exist in a vacuum; 


\section{Another interesting example} of Muslim women's gendered online campaigns to express and assert their diverse and hybrid gendered identities in cyberspace was the launch of the annual global campaign \#MuslimWomensDay neither are they generated by coincidence. Rather, they are reflective of long-held, deeply-rooted stereotypes $^{21}$ about Muslim women, who have been traditionally -falsely- depicted as submissive, repressed, and silenced; or as overly sexualized objects -or both- from a purely Orientalist, Western perspective.

Therefore, any serious attempt to counter Islamophobia must take into account and illustrate Muslim women's shifting identities, complex realities, multiple agencies, and varied resistances.

In 2016, Republican presidential nominee Donald Trump insinuated that Ms. Ghazala Khan's religion might have stopped her from speaking at the Democratic National Convention, when she stood beside her husband, Mr. Khizr Khan, on stage. Soon after, Ms. Khan stood up for herself and spoke out in a televised interview, explaining that she remained silent only after seeing a displayed photo of her martyred son, a Muslim American fallen soldier, which made her very emotional. ${ }^{22}$ In response to this incident, other Muslim women started a far-reaching Twitter campaign using the hashtag \#CanYouHearUsNow to show just how powerful, strong, vocal, and outspoken they are, exhibiting clear examples of their successes and achievements in various professional fields. In other words, they effectively and powerfully countered and 'resisted' the distorted stereotype of the silenced, oppressed, and marginalized Muslim woman by making their 'voices' heard, loudly and clearly, through this Twitter campaign. ${ }^{23}$

Many of the tweets in this massive campaign went viral on Twitter, spilling over into mainstream media. Here are a few examples, among many. A tweet from the Washington D.C.-based group Karamah ${ }^{24}$ (Muslim Women Lawyers for $\mathrm{Hu}-$ man Rights) proclaimed: "Today we raise our voices for Muslim women around the world who empower their community \#CanYouHearUsNow." American-Muslim activist Hind Makki, commenting on a photo of eighty American Muslim women speakers at the Islamic Society of North America (ISNA), declared, "Check out all these Muslim women speakers NOT silent at a major American Muslim conference \#CanYouHearUsNow." In a post displaying an image of Wonder Woman, Faiza N. Ali tweeted: "I'm an organizer, activist, public servant fighting 4 dignity and respect. Pretty much Wonder Woman \#CanYouHearUsNow." Rim-Sarah Alouane provocatively asked, “@realDonaldTrump 


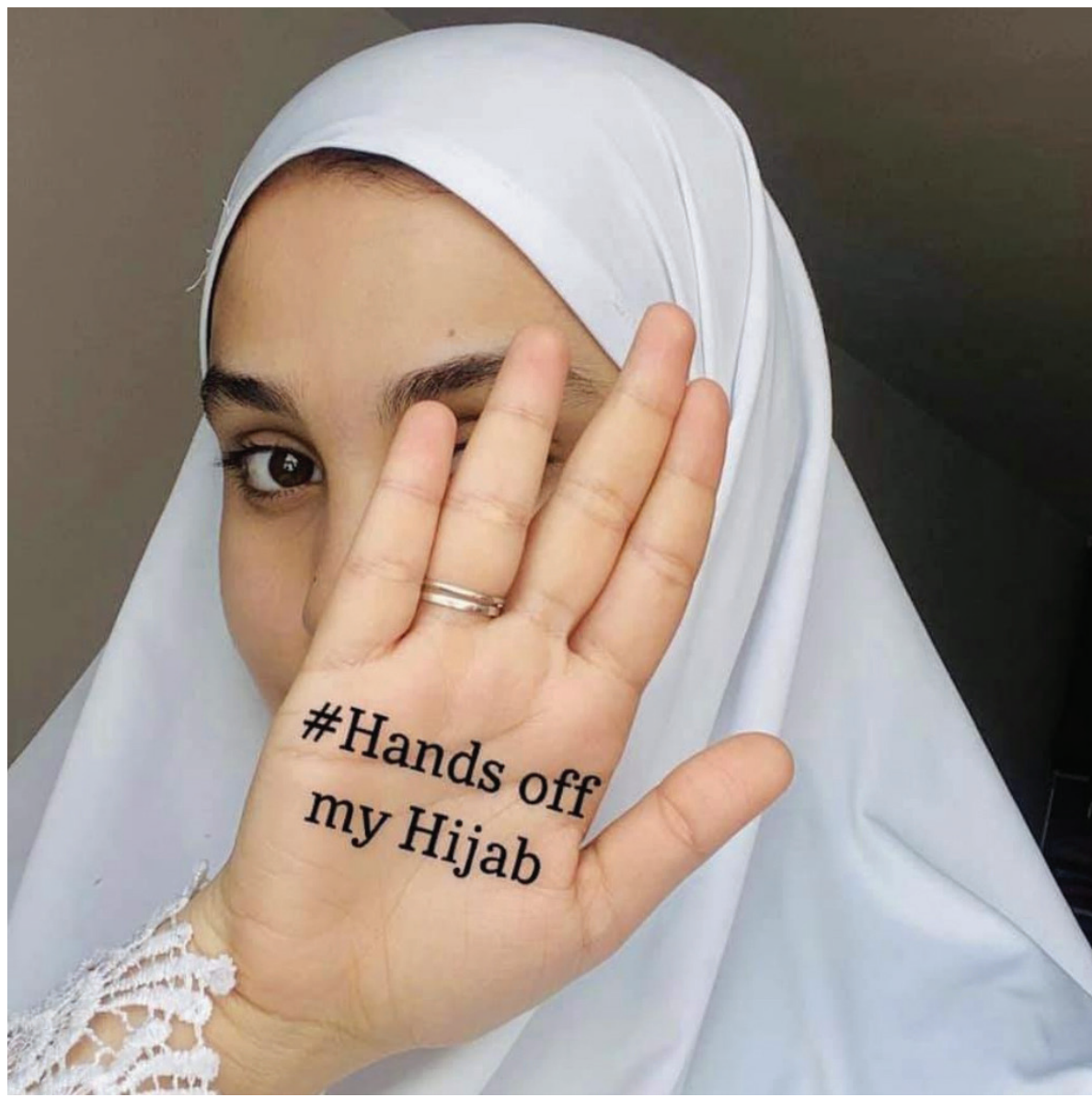

Muslim women in France protest the plans for banning the headscarf, which is on the agenda of politicians, with the 'Don't touch my headscarf' movement on social media.

I'm a \#humanrights scholar, trying to make sure rights and freedoms are protected. What do you do? \#CanYouHearUsNow." And Dalia Mogahed, co-author of the book Who Speaks for Islam? asserted: "Muslim women 'not allowed to speak?' I gave a @TEDTalks and got a standing ovation \#CanYouHearUsNow." ${ }^{25}$

In commenting on this influential online campaign, some mainstream media outlets described it as a powerful and effective effort to showcase the diverse voices, talents, and suc- cesses of Muslim women who -like journalists, activists, academics, and more- demonstrated how they regularly speak out to make the world a better place. ${ }^{26}$ The campaign was also praised for helping Muslim women take back their own narratives -especially at a time when their (mis) perceived oppression under Islam was being exploited as a means to implement discriminatory policies, and at a time when they are still the most frequent targets of hate crimes and bias incidents. The public impact of this campaign also reveals 
how social media democratizes voice sharing if used properly: amplifying voices often ignored by mainstream media while, at the same time, encouraging reporters and journalists to pay attention and communicate accurate stories. ${ }^{27}$ Other media outlets commended Muslim women for amplifying their voices, broadcasting their strength, and, most importantly, reclaiming the narrative from Trump while exposing his Islamophobic, sexist, and misogynistic rhetoric in a simple, agile, effective, and powerful manner. ${ }^{28}$

Another interesting example of Muslim women's gendered online campaigns to express and assert their diverse and hybrid gendered identities in cyberspace was the launch of the annual global campaign \#MuslimWomensDay on March 27, 2017. ${ }^{29}$ This idea was introduced by a young American-Muslim feminist and activist, Amani al-Khatahtbeh, in response to Trump's Muslim Travel Ban as a way to amplify Muslim women's voices and to boost the visibility of their obscured and/or misrepresented identities. It is worth noting that al-Khatahtbeh is the founder of a group blog called 'Muslim Girl' which subsequently became an online magazine and a foundation dedicated to increasing Muslim women's media representation and visibility, providing them with a safe space to reclaim their 'narratives' and to amplify their 'voices."

A number of Muslim women, representing different backgrounds and identities, used \#MuslimWomensDay on Twitter in 2017 to propagate their narratives of diversity and to assert their agency. In many of these tweets, women were pictured wearing hijabs as a way to assert their Muslim identities and to fight the pervasive idea that Muslim women lack agency. In one of these tweets, a woman shared a selfie with the caption, "About time we got a \#MuslimWomensDay. Perhaps it's a step towards being heard inshallah. \#TraditionallyUnsubmissive \#Muslimah." ${ }^{31}$

On its $5^{\text {th }}$ anniversary in 2021, \#MuslimWomensDay provided another excellent opportunity for many Muslim women from different walks of life to represent their diverse identities through a number of tweets and posts on a number of social media platforms, including Twitter, Facebook, Snapchat, and Instagram. Many of these posts combined text with visual imagery -photographs, selfies, videos- marking another example of how Muslim women utilize the digital sphere to amplify their messages and share them with a widely diverse global audience -expressing and negotiating their individual identities while challenging the commonly held misconceptions and stereotypes, clouding their lived realities and varied experiences.

Other postings from the \#MuslimWomensDay 2021 global campaign included a tweet from a young Muslim woman, Shahed Ezaydi: "A happy \#MuslimWomensDay to all Muslim women everywhere! We are constantly sidelined, silenced, and excluded, so today is a day to listen 
and pass the mic to Muslim women." Similarly, another Muslim woman, tweeting as 'King Marwa', declared, "Happy \#MuslimWomensDay. Being a Muslim woman means everyone around you has ideas about who you are and what you believe in. I encourage you to speak to a Muslim woman and understand where we come from and OUR beliefs. Not the lies the media and false sources like to give. It is OUR narrative." This tweet was coupled with a drawing of a hijabi-wearing Muslim woman carrying a sign that stated, "Muslim Women Do Not Need Saving." 32

These shining examples illustrate how Muslim women are able to effectively exercise their 'agency' online by effectively utilizing the opportunities made possible in cyberspace to 'resist' misrepresentation, stereotyping, profiling, and marginalization. ${ }^{33} \mathrm{By}$ engaging in these gendered online struggles, it can be said that Muslim women are fighting two parallel battles simultaneously: one against the negative stereotypes about Islam and Muslims in general, and another against the false misrepresentations and misperceptions of Muslim women in particular.

\section{Conclusion}

Despite the negative wave of Islamophobia that has been on the rise in recent years in many parts of the world, especially in Europe and the United States, it is important to highlight one positive aspect, which is the lessons learned by new generations of

\section{It is safe to conclude that}

these future dynamics will certainly magnify the dual role of the internet as a perfect platform for spreading -and simultaneously countering-Islamophobia

young Muslims. Many young Muslims today, especially those who live in diasporic communities outside their own home countries, are realizing the importance of becoming proactive, rather than reactive, when confronting hatred and profiling, both offline and online. ${ }^{34}$

As part of their struggle to rectify many of the false images associated with Islam and Muslims, modern Muslims are engaging in organized online efforts to spread accurate awareness and correct misinformation, rather than being on the defensive, realizing that this is the best way to further engage non-Muslims, and lead them away from Islamophobic tendencies. In doing so, many of them have realized that ignoring the problem will not make it go away. Therefore, they have begun to actively change public opinion and media perceptions through positive messages, using the very same tools of digital media that have been used against them.

It is only realistic to predict that future generations of young Muslims 
will exert more efforts to reach out to mainstream media, while also making use of new media platforms, such as online discussion forums and Twitter campaigns, to amplify their message of resilience and resistance. This marks the emergence of a heterogeneous, virtual ummah that mirrors the transformation, hybridization, and negotiation of Muslim identities, as they constantly oscillate between various push-and-pull forces, such as tradition and modernity, ${ }^{35}$ while engaging in parallel struggles against marginalization, stigmatization, and misrepresentation, both in real life and in cyberspace.

This is especially important in the current era of digital communication, where most people get their news and engage in all forms of communication online, and it is likely to become even more important, moving forward, as more people become technologically savvy and internet-dependent. It is safe to conclude that these future dynamics will certainly magnify the dual role of the internet as a perfect platform for spreading -and simultaneously countering- Islamophobia.

\section{Endnotes}

1. Mohammed el-Nawawy and Sahar Khamis, Islam Dot Com: Contemporary Islamic Discourses in Cyberspace, (New York: Palgrave MacMillan, 2009).

2. "Islamophobia: Understanding Anti-Muslim Sentiment in the West," World Gallup Online, (2018), retrieved from http://news.gallup.com/ poll/157082/islamophobia-understanding-anti-muslim-sentiment-west.aspx.

3. David Tyrer, The Politics of Islamophobia: Race, Power and Fantasy, (London: Pluto Press, 2013), p. 3.
4. Martin Asser, "What the Muhammad Cartoons Portray," BBC News, (January 2, 2010), retrieved from http://news.bbc.co.uk/2/hi/middle_east/46 93292.stm.

5. Gordon Conway, "Islamophobia: A Challenge for Us All," The Runnymede Trust Commission on British Muslims and Islamophobia, (London: London Runnymede Trust, 1997).

6. Shawn Armstrong, Islam, a Religion of Peace: An Inconvenient Truth, (2016), retrieved from https:// books.google.com/books?id=ZBggDQAAQBAJ\&pg=PP1\&lpg=PP1, p. 188.

7. Hud Lesprit, "France Bans Hijab for Anyone Under 18 - Secular Tyranny Rises," The Muslim Sceptic, (April 1, 2021), retrieved from https://muslims keptic.com/2021/04/01/france-bans-hijab-foranyone-under-18-secular-tyranny-rises/.

8. Stephen Croucher, "French-Muslims and the Hijab: An Analysis of Identity and the Islamic Veil In France," Journal of Intercultural Communication Research, Vol. 37, No. 3 (2008), pp. 199-213.

9. "French 'Burqa Ban' Violates Human Rights, Rules UN Committee," DW, (October 23, 2018), retrieved from https://www.dw.com/en/frenchburqa-ban-violates-human-rights-rules-un-committee/a-46007469.

10. Sahar Khamis, "American-Muslims' E-Jihad: Trumping Islamophobia in the Trump Era," CyberOrient, Vol. 12, No. 1 (2018), retrieved from http:// www.cyberorient.net/article.do?articleld=9923.

11. "Timeline of the Muslim Ban," ACLU of Washington, retrieved from https://www.aclu-wa.org/ pages/timeline-muslim-ban.

12. Khamis, "American-Muslims'E-Jihad."

13. Johan Farkas, Jannick Schou, and Christina Neumayer, "Cloaked Facebook Pages: Exploring Fake Islamist Propaganda in Social Media," New Media and Society, Vol. 20, No. 1 (2017), pp. 18501867, p. 1850.

14. Farkas, Schou and Neumayer, "Cloaked Facebook Pages."

15. "\#banislam Tweets," Twitter, retrieved from https://twitter.com/hashtag/banislam?lang=en.

16. "\#banislam Tweets."

17. "American Muslims: Facts vs. Fiction," Unity Productions Foundation, retrieved from https:// www.youtube.com/watch?v=eFsn49Qxwl0.

18. "\#MuslimsAreSpeakingOut," FFEU, retrieved from https://ffeu.org/muslim-jewish/muslims-are -speaking-sut/. 
19. Islamophobin, retrieved from http://www.lslamophobin.org.

20. "Muslims Report Stuff," Twitter, retrieved from https://twitter.com/muslims_report?lang=en.

21. Anoosh Soltani and Hannah Thinyane, "How Muslim Women Break Stereotypes by Mixing Faith and Modesty with Fashion," The Conversation, (July 11, 2019), retrieved from https://theconversation.com/how-muslim-women-breakstereotypes-by-mixing-faith-and-modesty-withfashion-110767.

22. Khamis, "American-Muslims' E-Jihad."

23. Khamis, "American-Muslims' E-Jihad."

24. Karamah means 'dignity' in Arabic.

25. "Muslim Women Ask: Can You Hear Us Now?" Twitter, retrieved from https://twitter.com/i/event s/760197573839876097?lang=en.

26. "\#CanYouHearUsNow," Shorty Awards, retrieved from https://shortyawards.com/2nd-socialgood/canyouhearusnow.

27. "\#CanYouHearUsNow."

28. "Muslim Women Broadcast Their Strength with \#CanYouHearUsNow," Waging Nonviolence, (August 2, 2016), retrieved from https://wagingnonviolence.org/2016/08/muslim-women- broadcast-their-strength-with-canyouhearusnow/.

29. Rosemary Pennington, "Making Space in Social Media: \#MuslimWomensDay in Twitter," Journal of Communication Inquiry, Vol. 42, No. 3 (2018), pp. 199-217.

30. Amani al-Khatahtbeh, Muslim Girl: A Coming of Age, (New York: Simon and Schuster, 2016).

31. Pennington, "Making Space in Social Media," p. 206.

32. Shahed Ezaydi, Twitter, 2:51 PM, (March 27, 2021); King Marwa, Twitter, 9:10 PM, (March 27, 2021), retrieved from https://muslimgirl. com/20-tweet-highlights-from-our-fifth-annual-muslimwomensday/.

33. El-Nawawy and Khamis, Islam Dot Com.

34. Sahar Khamis, "The Internet and New Communication Dynamics among Diasporic Muslims: Opportunities, Challenges and Paradoxes," in Merve R. Kayıkcı and Leen D'Haenens (eds.), European Muslims and New Media, (Leuven: Leuven University Press, 2017), pp. 35-52.

35. Gary Bunt, Hashtag Islam: How Cyber-Islamic Environments Are Transforming Religious Authority, (Chapel Hill: University of North Carolina Press, 2018). 


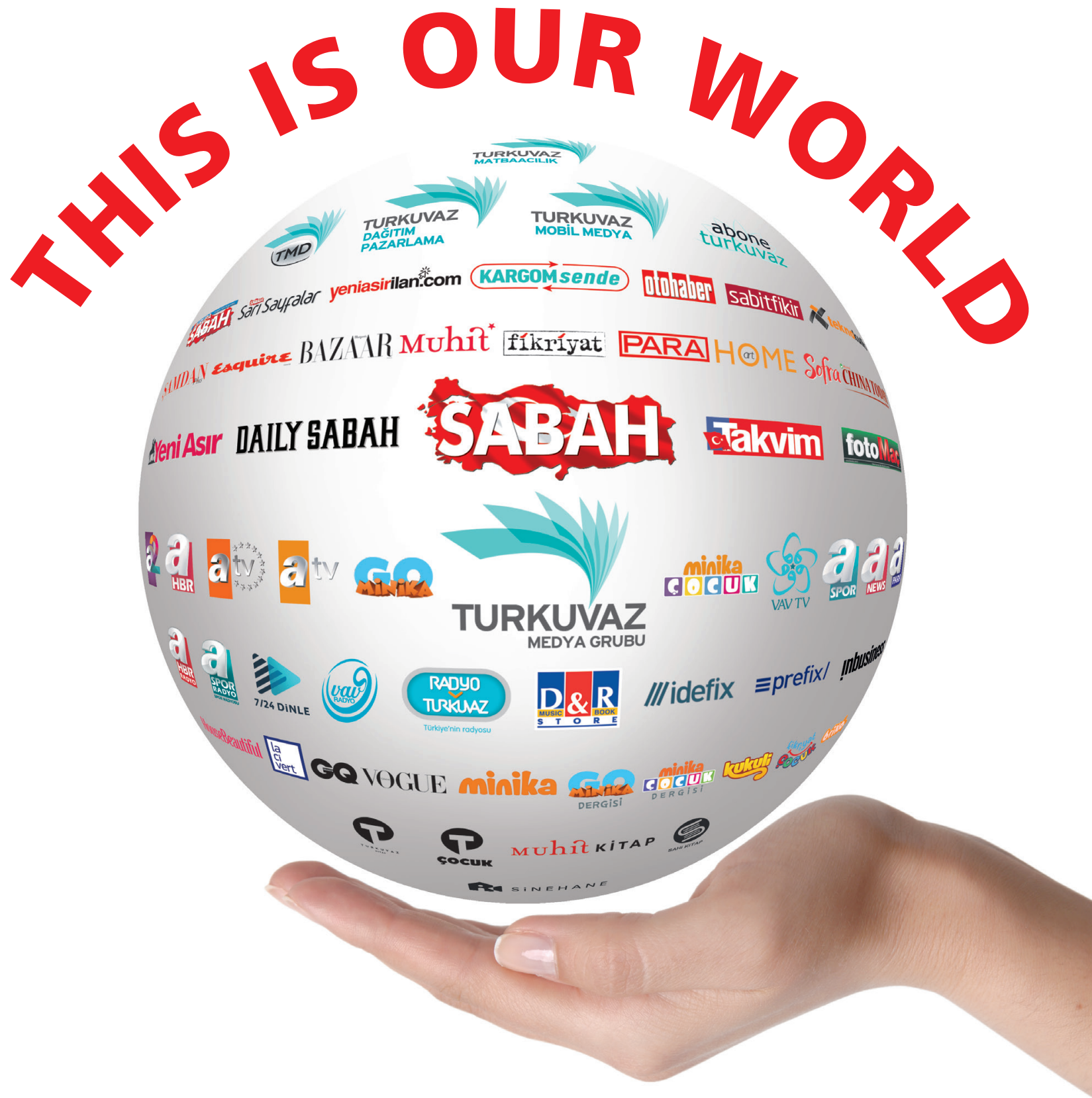

Turkuvaz Media Group is the leading group of companies which deals with broadcasting, publishing and distribution activities in Turkey. Most reputable national and international magazines, best selling local and national newspapers and prestigious tv channels create the most powerful synergy in Turkish media.

The opportunity to utilize this power for your advertisements is in your hands.

Why not use it? 